\title{
HACIENDO EL JARDÍN DE LAS DELICIAS. FICCIÓN Y REALIDAD EN RELACIÓN A LOS ÁMBITOS DE RECREO PÚBLICO DECIMONÓNICOS*
}

\author{
POR \\ EVA J. RODRÍGUEZ ROMERO \\ Departamento Historia de Arte (C.E.H.) \\ JOSÉ MANUEL PRIETO GONZÁLEZ \\ Departamento Historia de la Ciencia (C.E.H.)
}

\begin{abstract}
Different components concuring in the gradual gestation of public recreation spaces in Spanish society, especially at Madrid, since the first decades of the $19^{\text {th }}$ century is study. This analysis is based on two kinds of work material: of a part, built works and, of other, academic projects never carried to practice, that served for the attainment of several Architect titles.
\end{abstract}

La Revolución francesa trajo aparejados cambios importantes en lo que se refiere a la estimación de lo público y lo privado, que se dejaron sentir especialmente en el ámbito de la arquitectura. En su rebelión contra el privilegio y la diferencia, las masas reclamaron para sí el disfrute de ciertos placeres que hasta entonces sólo habían estado al alcance de unos pocos; la lectura, por poner un ejemplo, se veía enormemente limitada fuera de las bibliotecas particulares, con independencia de que la mayor parte de la sociedad fuese iletrada. Dado que los revolucionarios franceses cifraron además en la lectura uno de los derechos del hombre, la promoción de bibliotecas públicas será una constante a partir de entonces. Pero, probablemente más apreciado que el de la lectura, el grueso de la sociedad valoró sobremanera el derecho a otras formas de pasar el tiempo libre, siendo el paseo la que parece más a propósito para aglutinar a todas las demás. Ocio y diversión, que se manifestaban también a través del baile, de los juegos de azar, de los ejercicios gimnásticos, o simplemente del contacto tranquilo y sosegado con la naturaleza, precisaban pues de zonas de esparcimiento convenientemente equipadas (jardines, galerías, estanques, pórticos, cenadores, fuentes, pabellones de diversa índole, etc.). Algunos de los que antaño habían sido entornos privados para disfrute de reyes, príncipes y aristócratas, fueron convirtiéndose paulatinamente en ámbitos de solaz comunal; con el tiempo, éstos serán el

\footnotetext{
* Este artículo se continuará en otro posterior donde se estudiarán diversos elementos que constituyen dichos ámbitos de recreo, como cenadores o templetes de jardín, elementos escultóricos en plazas y paseos, diferentes edificaciones en jardines de recreo, etc..., a través de proyectos de alumnos comparados con ejemplos construidos en la realidad.
} 
resultado de creaciones ex novo orientadas directamente a tal fin, dando así respuesta a las directrices gubernamentales emanadas de un programa ilustrado con vocación urbana y civil. En este sentido, nuestro propósito no consiste sino en aportar luz sobre esa etapa de transición, haciendo hincapié sobre todo en los elementos que intervienen en el proceso de configuración de los espacios de recreo público. Para ello, nos ha parecido oportuno tratar el problema confrontando teoría y práctica; así, proyectos limitados a la superficie del papel —«imágenes de lo posible» que diría Delfín Rodríguez - en los que alumnos-arquitectos de la vieja Academia y de la nueva Escuela de Arquitectura ${ }^{1}$ desarrollan temas de esta naturaleza en el marco de las pruebas finales para obtener la titulación, se ponen en relación con obras y proyectos realmente construidos, concretamente en Madrid, siendo éstos verdaderos exponentes de lo hecho en el resto de España y correlato de la imagen mental que, en relación a este tema, albergaba el colectivo arquitectónico que se encontraba en ejercicio en el tercio central del siglo XIX.

A remolque de El Jardín de las Delicias de El Bosco son muchas las sugerencias, conceptuales e iconográficas sobre todo, que, de cara al asunto que estamos tratando, nos ha proporcionado el famoso tríptico del Prado. En efecto, el jardín se ha venido asociando tradicionalmente con lugares placenteros, paradisíacos y deliciosos, en los que el hombre disfruta y se encuentra a gusto; así lo reflejó Hieronymus Bosch en pleno Renacimiento y así lo entendió también la sociedad madrileña del siglo XIX cuando denominó a más de un paseo como «de las Delicias» ${ }^{2}$, pudiendo considerar el paseo como una sucesión de jardines. Como buen jardín, el pintado por El Bosco combina el medio acuático — fuente incluida - con amplias zonas verdes, pequeñas agrupaciones boscosas y construcciones de enorme efectismo que recuerdan las exóticas y sorpresivas creaciones del modelo paisajista inglés, caracterizado por la organización irregular de los jardines. Sin embargo, no era el placer irracional y llevado al paroxismo que revela la popular tabla, el que se perseguía en estos espacios de recreo concebidos en la pasada centuria. De hecho, podemos contraponer la concupiscencia, el desenfreno y los «vicios humanos» reflejados en la pintura a las saludables virtudes, físicas y psíquicas, higiénicas en definitiva, inherentes a la decimonónica cultura del paseo. Nuestra pretensión, por tanto, no es otra que la de recrear, a partir de la suma de aportaciones - teóricas y prácticas- de distintos profesionales de la arquitectura y la jardinería, un ideal jardín de las delicias, en sentido positivo, que esté integrado por piezas de diversa índole (jardines, fuentes, pórticos, cenadores...).

Nos remitimos además a la idea de la existencia de una analogía formal entre la ciudad y el jardín ${ }^{3}$, siendo esta analogía directa en el caso del jardín clásico regular pero más sutil en el caso del

1 Sobre la segregación de la Escuela de Arquitectura con respecto a la Academia de San Fernando, véase Navascués Palacio, Pedro: «La Escuela de Arquitectura de Madrid (1844-1914)», en Escuela Técnica Superior de Arquitectura de Madrid. Memoria 1991-1993, Instituto Juan de Herrera, Madrid, 1994, pp. 10-17.

2 A mediados del siglo XIX, Madrid contaba con dos paseos que llevaban ese nombre. El llamado de las Delicias de Isabel II era, según Pascual Madoz, un «magnífico paseo» que empezó a realizarse en los últimos años del reinado de Fernando VII y que, desde la puerta de Recoletos, se extendía en dirección norte. El otro, conocido como Paseo de las Delicias (pintado por Francisco Bayeu en 1785), comenzado por Fernando VI y mejorado por Carlos III, iba desde la puerta de Atocha hasta el puente de Santa Isabel, sobre el Canal del Manzanares (Madoz, Pascual: Madrid. Audiencia, Provincia, Intendencia, Vicaría, Partido y Villa. Ed. facsímil de la de 1848, Ábaco Ediciones, Madrid, 1981; págs. 406 y 409). En relación con la idea que venimos sosteniendo, dice Madoz del primero de esos paseos que «por su situación, comodidad y belleza es uno de los más agradables y de los que prestan hermosura y distracción a la corte»; y es que «un estéril arenal quedó convertido en agradables jardines» (opus cit., pág. 406). El segundo paseo, que, según parece, discurría entre praderas y dehesas próximas al río, habría perdido parte de su encanto al inaugurarse la estación de ferrocarril; estación, por cierto, que se apropió del nombre del paseo pero no de su apacible tranquilidad. Por lo demás, en atención a la definición que, de la voz «Delicias», daba el Diccionario del P. jesuíta Esteban de Terreros, publicado en 1786, un paseo de las Delicias sería aquel «que causa muchos gustos a un tiempo» (Terreros y Pando, Esteban de: Diccionario Castellano con las voces de Ciencias y Artes. Ed. facsímil de la de 1786, Arco Libros, Madrid, 1987; tomo I, pág. 604).

3 Cfr. Aníbarro, Miguel Ángel: «La ciudad vegetal», Anales de Arquitectura, Universidad de Valladolid, n. ${ }^{\circ} 1,1989$, pp. 18-27. 
jardín paisajista, estilo que en esta primera mitad del siglo se está extendiendo en nuestro país ${ }^{4}$. En efecto, el paralelismo entre el trazado del jardín clásico y el trazado de la ciudad es evidente, incluso comparten la terminología de sus elementos y ámbitos estanciales (calles, plazas, glorietas... ${ }^{5}$, sin embargo esta analogía resulta menos inmediata cuando se trata de confrontar la ciudad decimonónica y el jardín paisajista. Podemos basarnos en la posibilidad de concebir la ciudad como un paisaje público donde se imbrican los usos privados con otros usos semipúblicos y con los usos verdaderamente públicos, los más importantes en la ciudad. La ciudad se puede entender como una suma de espacios creados para el recreo público, si es que nos estamos refiriendo a la costumbre del paseo, por ejemplo; además esas sucesivas formas recorribles que configuran una ciudad se pueden poner en paralelo a la sucesión de escenas y ámbitos que conforman el jardín paisajista. Por otro lado, es en el siglo XIX cuando ciudad y jardín tendrán una relación más íntima: las teorías higienistas de la ciudad ven en los parques, los jardines y los paseos arbolados no sólo un medio de embellecer la ciudad, sino sobre todo una necesidad indispensable; los jardines proporcionan sosiego y bienestar al espíritu pero también aire puro y salud dentro de una ciudad que cada vez es más extensa, que pierde, a su pesar, el contacto con la naturaleza. El jardín será en la ciudad del XIX esa naturaleza cautiva y humanizada para el esparcimiento, en añoranza de la verdadera naturaleza que cada vez resulta más inalcanzable al haberse extendido tanto los límites de la ciudad. Ciudad decimonónica y jardín son inseparables: habrá jardines privados en los palacetes urbanos, jardines semipúblicos en las nuevas casas de vecindad, jardines interiores en el corazón de las manzanas de los ensanches y, sobre todo, extensos parques públicos, plazas ajardinadas y cientos de metros de calles arboladas donde todos puedan desarrollar todas las actividades propias de la vida de la ciudad $^{6}$. Cada nueva tipología de desarrollo urbano lleva aparejada su propia manifestación jardinera. Hay que resaltar también que el estilo de jardín que se emplea mayoritariamente es el jardín paisajista, que habiendo nacido en las casas de campo de la aristocracia ilustrada se apropia de la ciudad y se expande en los nuevos parques públicos de toda Europa e incluso en América.

Toda la ciudad puede ser un jardín ${ }^{7}$, los caprichos de la escenografía típica de un jardín paisajista se deben ir descubriendo en un recorrido sinuoso y sorpresivo, un recorrido casi iniciático

\footnotetext{
${ }^{4}$ El jardín paisajista surgió como una rebelión contra la excesiva geometrización de los jardines barrocos. El nuevo estilo supuso una verdadera «revolución jardinera» en cuanto a las formas del jardín, el cuál se trazaría ahora sobre terrenos ondulados, surcado de sinuosos caminos, con espesa vegetación distribuida en bosquetes y lagos o cursos de agua naturalistas. Esta rebelión comenzó en Inglaterra en torno a 1720, por lo que el jardín paisajista también se denomina jardín inglés, aunque según los países donde después se cultivará tendrá diversas nomenclaturas. Pero este tipo de jardín no es sólo un fenómeno dieciochesco e inglés: ya desde mediados del XVIII, a impulsos de las ideas de la Ilustración, sustentadas por la nobleza crítica y la burguesía consciente de su propia importancia, esta jardinería conquistó todo el continente, se extendió desde Francia al resto de las cortes europeas llegando hasta Escandinavia, Rusia y América, siendo asumida también por reyes y emperadores allí donde el absolutismo se consideró ilustrado. Fue una larga fase en los estilos de jardinería, porque representó una de las principales actividades artísticas de su tiempo, hasta bien entrado el siglo XIX, cuando se da el movimiento de los parques urbanos que serán todos trazados siguiendo los principios del paisajismo, el cual continúa influyendo incluso notablemente en la jardinería moderna. Sobre el tema de la llegada y posterior difusión de este estilo jardinístico a España se pueden consultar los artículos de Carmen Ariza Muñoz: «Introducción del jardín paisajista en el Madrid del siglo XIX», Villa de Madrid, n. ${ }^{\circ}$ 97-98, 1988, pp. 80-89; y de Eva Rodríguez Romero: «El jardín paisajista y la mujer en España: la Alameda de Osuna, el Casino de la Reina y Vista Alegre», La mujer en el arte español, Ed. Alpuerto, Madrid, 1997, pp. 347-366.

5 Además, a veces jardín y ciudad se interrelacionan en su formación como fue el caso de París, donde el trazado de las Tullerías marcó el desarrollo de la ciudad hacia el Este.

${ }^{6}$ Sobre las diversas relaciones del jardín con el urbanismo en el caso de la ciudad de Madrid, ver Victoria Soto Caba: «Del capricho al paisaje, jardín y urbanismo en el Madrid del siglo XIX», Reales Sitios, n. ${ }^{\circ} 120,1994$, pp. 40-46.

${ }^{7}$ El caso extremo de la imbricación de estas dos realidades en un mismo diseño unitario serán las ciudades-jardín, como la famosa Ciudad-jardín de Howard e incluso la española Ciudad Lineal de Arturo Soria, que se desarrolla a lo largo de un bulevar central y con jardines en el frente y en la parte posterior de las casas. De todas maneras, con la expresión «toda la ciudad puede ser un jardín» nos referimos no tanto a los casos en los que ésto ocurre literalmente, sino a una manera de percibir la ciudad, una manera de recorrerla, independientemente de que el trazado urbano sea muchas veces en cuadrícula y el trazado del jardín más libre y orgánico.
} 
en el que van apareciendo desde puntos de vista tangenciales nuevos focos de atención que nos invitan a continuar el paseo. Esta forma de recorrer las diversas escenas del jardín, única manera posible de disfrutar y conocer un jardín paisajista, pueden equipararse al «flâner ${ }^{8}$ urbano de plazas a paseos, de éstos a galerías, a pequeños squares con sus templetes y estatuas, de calles a los jardines de los parques poblados por sus propios caprichos y construcciones recreativas. Toda la ciudad, para el paseante sensible que la recorre ávido de imágenes, puede convertirse en un jardín de las delicias.

El jardín paisajista deja de aparecer como jardín exclusivamente campestre mientras comienza a surgir como jardín urbano, en un proceso de apropiación por parte del naciente urbanismo moderno de las maneras de generar espacios propias del jardín. Debemos recordar que es a principios del siglo XIX cuando se produce el nacimiento del urbanismo como tal ciencia ${ }^{9}$, se desempolvan las viejas ideas hipodámicas, las visiones ideales del renacimiento y las intervenciones magníficas y lineales del barroco y junto con las nuevas ideas funcionales e higienistas se crea todo un corpus teórico e ideológico que desemboca en la organización y la práctica de las reformas en todas las grandes ciudades europeas. La ciudad había crecido desmesuradamente, debido a los cambios demográficos, sociales y económicos derivados de la Revolución industrial, con lo que, en la mayoría de los casos, para evitar el caos y poner orden al proceso imparable, se combinaron la planificación del ensanche de las ciudades con reformas interiores en las mismas, que saneasen la ciudad y conectasen los viejos cascos urbanos con las nacientes ciudades ex novo a su alrededor.

Desde los comienzos del nuevo urbanismo la naturaleza está presente ${ }^{10}$ siempre en la ciudad, en la forma idealizada y humanizada o incluso «artificializada» de jardín. En Londres se dio el movimiento a favor de los public walks, el nuevo crecimiento urbano se organizó sobre la base de grandes squares rodeados de terraces o casa en hilera, apareciendo también nuevas tipologías urbanas como el circus y el crescent (con bloques de viviendas curvos, a veces formando ondulaciones en las calles mediante varios de ellos), junto con encadenamientos de plazas ${ }^{11}$. En estos nuevos desarrollos de ciudad se emplean mecanismos para que la trama urbana pueda crecer produciendo a la vez una apertura de dicha trama y posibilitando la aparición del paisaje dentro de la ciudad; se asume la línea ondulada del jardín paisajista en la planta de los edificios e, incluso, en el alzado de los mismos, mediante escalonamientos cuando las calles están en pendiente. Se preferirá el paisaje urbano accidentado e irregular, como ponía de manifiesto, ya a

${ }^{8}$ Empleamos este término francés que significa deambular, callejear, porque encierra connotaciones ajenas a nuestros términos equivalentes que lo hacen especialmente apropiado para lo que queremos expresar.

9 Sobre historia del urbanismo en esta época se pueden consultar en sus ediciones españolas el estudio bastante general de Leonardo Benevolo: El arte de la ciudad contemporánea. Diseño de la ciudad, vol. 5., Ed. G.G., Barcelona, 1982 y el más extenso y completo de Paolo Sica: Historia del urbanismo. El siglo XIX, 2 vol., Instituto de Estudios de la Admón. Local, Madrid, 1981.

${ }^{10}$ Cfr. Chadnick, George F.: The Park and the Town, Frederick A. Praeger, Nueva York, 1966. Por otro lado, también a comienzos del XIX, a la vez que el jardín invade la ciudad, aparecen propuestas que integran totalmente la ciudad en la naturaleza donde se encuentra inmersa. Se trata de las ciudades utópicas intentadas por Owen y Fourier, por ejemplo.

"Son ejemplos emblemáticos las actuaciones de John Nash en el Royal Crescent, Regent's Park y Regent's Street en el primer tercio del siglo XIX. El regente decide realizar una empresa especulativa en su propiedad, construyendo un barrio para la alta sociedad donde se viviese como en el campo, pero con todas las ventajas de vivir en la ciudad. Las viviendas, en forma de terrace, circundan un gran parque (de trazado paisajista, e incluso con su propio zoológico) del que parte Regent's Street, que atravesando Picadilly Circus y Oxford Street y, tras hacer diversos quiebros para respetar edificios existentes como la capilla Hannover, desemboca en Portland Place, frente a Saint James Park. El resultado es un circuito urbano concebido al modo de cómo se hacían los recorridos en un jardín paisajista, un circuito abierto. Cfr. Rasmussen, Steen E.: London, the Unique City (1934). The MIT Press, Londres, 1982 y Watkin, Davis: The English Vision: the Picturesque in Architecture. Landscape and Garden Desing, Harper \& Row, Nueva York, 1982. También son interesantes las concatenaciones de plazas y espacios públicos que desarrolla a partir de 1828 John Wood en la ciudad de Bath. 
finales del siglo XviII, el académico Reynolds ensalzando la reconstrucción de la city de Londres tras el incendio del XVII, que se había llevado a cabo siguiendo el antiguo trazado irregular. A la vez, aparecen los parques en los bordes de las ciudades, antes propiedades reales o de la aristocracia que ahora son abiertas al público, como otra forma de crecimiento de la ciudad (Saint James Park, Green Park, Hyde Park, Kensington Gardens...).

En París están teniendo lugar las reformas promovidas por el barón Haussmann, que darán lugar al nacimiento de los bulevares, dentro de un sistema escalonado de espacios urbanos formado por numerosas plazas (a la manera de los squares londinenses), galerías semicubiertas y cubiertas, jardines de invierno (más avanzado el siglo, cuando se extiende la arquitectura del hierro)... a la vez que las viejas posesiones reales se transforman en inmensos parques periurbanos (El Bois de Boulogne, el Bois de Vincennes y Monceau, como parque interior) y se crean nuevos parques en el corazón de la ciudad, todos ellos paisajistas (Buttes Chaumont, Montsouris) ${ }^{12}$. Todos estos parques formarán un sistema completo de espacios ajardinados en la ciudad a los que, más adelante, se le añadirán otros espacios públicos de recreo como son los recintos creados para las exposiciones universales.

En España esta relación tan estrecha entre arquitectura y urbanismo no se dio hasta el segundo tercio del siglo XIX ${ }^{13}$. La Guerra de la Independencia había paralizado toda posible expansión de la ciudad de Madrid, por la necesidad de fortificarla ${ }^{14}$. Sólo se realizó alguna modificación interior, llevada a cabo por el arquitecto Silvestre Pérez bajo encargos de José Bonaparte, al que se le conocía con el sobrenombre de Rey Plazuelas, que serán el origen, junto con la desamortizaciones posteriores, de las futuras plazas ajardinadas. Posteriormente, durante la etapa fernandina, las necesidades del país impidieron cualquier mejora urbana debido a los problemas económicos; sin embargo, este monarca sí realizó notables mejoras en los jardines de los Sitios Reales contribuyendo a la expansión del estilo paisajista en nuestro país, a la vez que potenciaba sobre todo la faceta productiva de dichos Sitios para solventar la susodicha situación económica ${ }^{15}$.

El reflejo de este retraso en la aplicación de los nuevos preceptos urbanísticos en España, queda patente en la ausencia de una enseñanza específica sobre urbanismo. Aunque, a partir de 1786, abundan como temas propuestos para los premios de la Academia proyectos situados idealmente en algún lugar concreto de Madrid, no es — como apunta Delfín Rodríguez ${ }^{16}$ - para resaltar la dimensión urbana de esos proyectos, sino simplemente por ocupar un lugar. Se proyecta sobre la ciudad, sobre la trama urbana, pero cabe preguntarse si existe una hipotética arquitectura de la ciudad. Aunque cada vez abundan más, conforme avanza el siglo XIX, los temas relacionados con los espacios públicos ${ }^{17}$ tanto en los ejercicios para los premios de la Academia

${ }^{12}$ Cfr. Alphand, J. C. A.: Les promenades de Paris (1867-1873), ed. fc. Princeton Architectural Press, Princeton, 1984.

${ }^{13}$ Sobre las transformaciones urbanas en Madrid durante el siglo XIX consultar el capítulo «Transformación urbana de Madrid durante el reinado de Isabel II. Las reformas interiores y el ensanche» del libro de Pedro Navascués Palacio: Arquitectura y arquitectos madrileños del siglo XIX, Insto. de Estudios Madrileños, 1973, pp. 140-170. También Ruiz Palomeque, Eulalia: Ordenación y transformaciones urbanas del casco antiguo madrileño durante los siglos XIX y XX, Instituto de Estudios Madrileños, 1976. Sobre el ensanche de Madrid, realizado a partir de 1860, cfr. Castro, Carlos M. ${ }^{a}:$ Memoria descriptiva del anteproyecto de ensanche de Madrid, Madrid, 1860.

${ }_{14}$ Incluso se fortificó gran parte del Retiro (Plan du Fort du Retiro à Madrid, Biblioteca del Palacio Real de Madrid).

${ }^{15}$ Cfr. Ariza Muñoz, C.: «La jardinería de los Reales Sitios en el Madrid fernandino», Reales Sitios, n. ${ }^{\circ}$ 90, 1986, pp. 49-56. Aunque cabría preguntarse si estas mejoras se deben realmente al interés del monarca por los jardines o, más bien, a la iniciativa de sus sucesivas esposas, más interesadas que él en asuntos culturales y artísticos (cfr. Rodríguez Romero, Eva: «El jardín paisajista y la mujer en España: la Alameda de Osuna, el Casino de la Reina y Vista Alegre», op. cit.).

${ }^{16}$ Rodríguez Ruiz, Delfín: «Imágenes de lo posible: los proyectos de arquitectura premiados por la Real Academia de Bellas Artes de San Fernando» en VV.AA., Hacia una nueva arquitectura. Premios generales de arquitectura de la Real Academia de Bellas Artes de San Fernando (1753-1831), C.A.M., Madrid, 1992, pp. 29-31.

17 Así, en 1772, se proponían como temas para los premios de la Academia una Fuente en un Arco de Triunfo y una Fuente adornada de Arquitectura y Escultura; en 1781 una Puerta rústica de salida al campo; en 1784 un Cementerio y 
como en los proyectos fin de carrera y, a pesar de que en la práctica el urbanismo ya es un hecho, la enseñanza de esta ciencia no se institucionalizará hasta el plan de estudios de 1914, ya en la Escuela de la Arquitectura. De todas maneras, algunos alumnos ya habían dado muestras de preocupación por temas con cierta vocación urbana; trataban de integrar el proyecto arquitectónico en su entorno, diseñando también el espacio que rodeaba al edificio y partiendo, para el diseño del propio edificio, de nuevas premisas que facilitaban dicha integración. Aparecía así la necesidad de rodear el edificio, de recorrerlo, para saber cómo estaba organizado, cosa que no ocurre en los edificios clásicos de volúmenes puros y compactos que se perciben en un solo vistazo. Se buscaba realizar conjuntos de edificios «agradables», mezclados con la naturaleza de un jardín, dándoles «un tono más grato» para que los usuarios encontrasen «utilidad, comodidad y placer» ${ }^{18}$.

En la práctica real, la jardinería urbana en España es un fenómeno decimonónico por excelencia ${ }^{19}$, coincidiendo plenamente con el más generalizado movimiento jardinístico europeo. La conquista de los espacios públicos en detrimento de la privatización del jardín, la necesidad de la vegetación como consecuencia de los efectos degradantes de la industrialización y, sobre todo, la necesidad estética y espiritual del jardín como proyección del espíritu romántico, hacen que la jardinería pase a formar parte integrante del diseño urbano. Pero hay que tener en cuenta que ya desde la segunda mitad del XVIII fue práctica común la realización de paseos arbolados, se fundaron jardines botánicos en varias ciudades y también se produjo la apertura al público de ciertos jardines pertenecientes a la Corona ${ }^{20}$. En Madrid la ordenación de las residencias reales, los paseos y los espacios verdes se fueron integrando en el conjunto de la transformación urbana y el concepto de jardín público se desarrolló favorecido por la Ilustración; muchas ciudades españolas iniciaron el siglo XIX con los trabajos de embellecimiento urbano que se habían propuesto décadas antes y se habían visto interrumpidos por la invasión francesa.

Así, las reformas urbanísticas llevadas a cabo por Carlos III, a partir de su llegada desde Nápoles en 1759, son muchas y, además, la jardinería forma parte esencial en ellas, pues los grandes ejes proyectados se basan en la formación de amplios paseos arbolados, que cumplen la doble función, utilitaria y estética, que debe tener toda obra pública imbuida por el espíritu ilus-

un Arco Triunfal; en 1787 el tema sería Idear una Puerta Magnífica para esta Corte en el lugar de la de Atocha; en 1790 una Puerta Principal de ciudad... Son temas urbanos, pero la funcionalidad como último fin del urbanismo, queda relegada en ellos, pues la mayoría son temas que buscan el ornamento, la monumentalidad y el ensalzamiento de la monarquía en la ciudad (Hacia una nueva arquitectura...., op. cit,, Catálogo). Ni en estas fechas, ni después, en la primera mitad del siglo XIX, la temática académica propondrá nunca trazar un plan urbano, bien de ensanche, bien de apertura de una plaza... mientras en la práctica profesional son ya encargos habituales.

${ }^{18}$ Son palabras que Antonio Cellés empleaba para defender su proyecto de unos Baños Públicos (1805) de las duras críticas que había recibido de Silvestre Pérez por carecer de proporción en plantas y alzados, por su desorden compositivo y la no adecuación entre las partes y el todo... Las críticas se basaban en criterios vitruvianos y clasicistas que no respondían a los supuestos de partida del proyecto. Cellés respondió que sabía que haciendo un edificio compacto, en vez de dividido en grupos, no hubiera recibido las críticas, pero que él buscaba adecuarse a la utilidad y función de los baños... Había sustituido la belleza de Vitruvio por el placer, aproximándose así a las más nuevas teorías sobre la arquitectura autónoma (Hacia una nueva arquitectura..., op. cit., pp. 28-30). Consideraba, pues, como parte importante de su proyecto la relación con el entorno y la presencia de la naturaleza conciliadora alrededor.

19 Para este tema ver el capítulo sobre «Las novedades de la jardinería del siglo XIX. La jardinería urbana o municipal, los Jardines de Recreo, los jardines de edificios públicos y las zonas verdes de los cementerios» en Ariza Muñoz, Carmen: Los jardines de Madrid en el siglo XIX, El Avapiés, 1988, pp. 142-266.

${ }^{20}$ Sobre los diversos aspectos que se pueden distinguir en la jardinería dieciochesca española, con la llegada de la dinastía borbónica ver: Ariza Muñoz, Carmen: «Los jardines madrileños en el siglo XVIII», Madrid y los Borbones en el siglo XvIII: la construcción de una ciudad y su territorio, C.A.M., 1984, pp. 141-155; Añón Feliú, Carmen: «Armonía y ornato de la naturaleza en el Madrid de Carlos III», Carlos III, alcalde de Madrid, Ayto. de Madrid, 1988, pp.129-176; Ariza Muñoz, Carmen: «Carlos III y las zonas verdes de Madrid, capital del reino», El arte en las cortes europeas del siglo XVIII, 1989, pp. 82-90 y Añón Feliú, Carmen: «Nature et jardins dans l'Espagne du XVIII ${ }^{\mathrm{e}}$ siècle», Histoire des jardins de la Renaissance à nos jours, ed. Flammarion, París, 1991, pp. 277-288. 
trado $^{21}$. Este monarca buscaba el embellecimiento de la ciudad, pero también realizaría un proteccionismo agrícola mediante la ordenación del territorio; basándose en estos principios promovió la renovación y sistematización de espacios ajardinados, sobre todo en los Sitios Reales que fueron campo propicio para experiencias fisiocráticas y en la capital. Estas reformas relacionadas con el ámbito urbano se localizaron en tres puntos de la ciudad: la zona de Palacio, la zona sur de la ciudad y los $\operatorname{Prados}^{22}$.

En la primera zona se ordena la plaza alrededor de la Puerta de San Vicente que se convertirá en el punto focal de los paseos adyacentes, como el de la Florida, del cual partía un camino que enlazaba con el Pardo, y la calle de Palacio. Se mejoran también los caminos que unen la Corte con los Sitios Reales de Aranjuez, El Pardo y El Escorial. Los paseos y caminos se plantan de olmos y se van intercalando con plazas circulares o semicirculares, con estatuas, puertas o fuentes como fondos de las perspectivas. La anchura de los paseos permite más de una alineación de árboles, con lo que se convierten en zonas estanciales.

$\mathrm{Al}$ sur de Madrid se finaliza el trazado, empezado ya por Fernando VI, de los ejes que bajan desde Atocha hasta el río, formando dos tridentes: uno partía de la Puerta de Atocha y otro de la de Toledo. Estos paseos se plantan con diversas especies de árboles; uno de ellos se denomina precisamente Paseo de los Olmos y otro es el Paseo de la Acacias. Se une la Puerta de Atocha con la de Toledo con una ronda en la que se abren los nuevos portillos de Valencia y Embajadores, se plantan los alrededores del Puente de Toledo y los caminos hacia el convento de Atocha, Vallecas y Extremadura. Se comienza la gran obra de canalización del Manzanares donde, según Ponz, se plantaron dos millones de árboles y arbustos, entre ellos cien mil moreras.

La tercera gran reforma y quizás la más importante, es el Salón del Prado, donde se termina de cubrir el arroyo que cruzaba aquel sitio antiquísimo de recreo de todos los madrileños, y se realizan plantíos desde 1769 hasta 1779. El trazado general, diseñado en apropiada forma circoagonal, fue del ingeniero militar José de Hermosilla y las fuentes que lo adornan (Cibeles en una esquina del enlace con la calle de Alcalá, Apolo en el centro, Neptuno donde desembocaba la Carrera de San Jerónimo, las cuatro fuentes frente a la calle de las Huertas que se continuaría entre el Retiro y el Jardín Botánico, y la Fuente de la Alcachofa frente a la Puerta de Atocha) fueron planeadas por Ventura Rodríguez ${ }^{23-24}$. Este paseo, «uno de los mejores de Madrid, y el más cómodo a pie y en coche que puede imaginarse...», según Ponz, se completaba con un abundante arbolado dispuesto en varias hileras. La ornamentación y comodidad del mismo se hubiese visto aumentada de construirse el pórtico que Ventura Rodríguez ${ }^{25}$ proyectara para él.

${ }^{21}$ Antonio Ponz, con las descripciones y opiniones que aporta en su Viaje de España, y Benito Bails fueron claros exponentes del pensamiento urbanístico de su época, en el que la noción de la utilidad se unía a un sentido del paisaje donde «la belleza de los alrededores, la amenidad y anchura de sus avenidas, la adecuada disposición general de sus calles y disposición de sus plazas... contribuyen muchísimo a la hermosura de toda ella (la ciudad)». (Bails, Benito: Elementos de matemáticas..., tomo IX que trata de la Arquitectura Civil, Madrid, 1783).

22 Pero estas acciones urbanísticas perimetrales y radiales no supusieron una modificación del suelo urbano, pues continuaba vigente una ley que no permitía edificar fuera de las murallas. Faltó una visión más amplia que hubiera sentado las bases de un crecimiento armonioso de la ciudad. Lo que sí lograban estos paseos era enlazar la ciudad, antes encerrada en sí misma, con la naturaleza que la rodea.

23 Ventura Rodríguez describe sus intenciones para este paseo y el detalle de las obras a realizar para la instalación de las fuentes, en una memoria que acompañaba a las trazas que realizó para dichas fuentes. A.S.A., 1/116/2. (Transcrito íntegramente en el apéndice del artículo de Añón, «Armonía y ornato de la naturaleza en el Madrid de Carlos III», op. cit.).

${ }^{24} \mathrm{El}$ programa iconográfico planteado por Ventura Rodríguez ha sido intensivamente estudiado por Thomas Reese: «Hipódromos, carros, fuentes, paseantes y la diversión pública en España del siglo XVIII: un programa agrario y de la antigüiedad clásica para el Salón del Prado», en IV Jornadas de Arte. El arte en tiempos de Carlos III, CSIC, Madrid, 1989, pp. $1-47$.

25 «En el Paseo del Prado hace falta un pórtico... donde el pueblo pueda guarnecerse en las ocasiones de lluvias repentinas hasta dos, o tres mil personas; y hallándose la parte general y centro del Paseo, cual es el terreno que está debajo de 
En cuanto a los jardines botánicos, en 1755 había sido fundado en Madrid el del Soto de Migas Calientes, en el camino de El Pardo, que funcionó hasta que, a instancias de Gómez Ortega y del médico de cámara, Murcio Zona, y bajo el patrocinio del conde de Floridablanca, el rey Carlos III creó en 1774 el Real Jardín Botánico del Prado. Este establecimiento formaba parte del conjunto monumental y urbanístico que el monarca auspiciaba para las inmediaciones del nuevo Salón del Prado, en la «colina de las ciencias», donde Juan de Villanueva levantaba el Observatorio Astronómico y el Museo de Ciencias. El Jardín Botánico fue creado con el fin científico de la enseñanza de la Botánica primordialmente, aunque pronto pasaría a tener también un fin didáctico dirigido a una población más amplia, sin olvidar el fin, secundario en este caso, de hermosear la ciudad y el reciente Paseo del Prado $^{26}$. Se realizaron diversos proyectos para su trazado, sus edificios y su cerramiento, destacando las dos puertas monumentales que le dan acceso: la puerta principal del Paseo del Prado de Sabatini, cuya inscripción versa en latín «Carlos III, padre de la patria, restaurador de la botánica, la salud y recreo de sus vasallos», y la de la actual Plaza de Murillo de Juan de Villanueva.

Gran parte de la superficie de los jardines de los Reales Sitios, aunque seguían siendo propiedad de la Corona, se abrieron al público. Carlos III fue el iniciador de esta costumbre en 1767, cuando permitió que se visitase el Buen Retiro, aunque las personas que pretendiesen entrar en las zonas abiertas debían contemplar las estrictas condiciones para acceder a él ${ }^{27}$. Además introdujo dos nuevas funciones en este Real Sitio, como fue la funeraria, al crear un cementerio modelo para los servidores del Sitio, y la industrial con la fundación de la Real Fábrica de Porcelana en 1759. También el Retiro albergó a partir de 1778 la primera escuela de jardinería en España ${ }^{28}$. Se sustituyeron las tapias de la calle de Alcalá y del Paseo del Prado por elegantes verjas para mejorar la apariencia exterior del Real Sitio de cara a la ciudad y hacer más amable el encuentro de ésta con el lugar acotado. Por aquellos lados en los que el Retiro no lindaba con el Prado, fue rodeado de paseos de álamos negros. Es fácil imaginar el impresionante conjunto que debían formar el Salón del Prado con el Retiro, el Jardín Botánico y la Colina de las Ciencias como telón de fondo, al final del cual partían los amenos paseos que descendían hasta las orillas del río; la riqueza de relaciones espaciales entre los diversos ámbitos públicos y semipúblicos hacían, sin duda, de esta zona de la capital la más agradable y propicia al paseo, así como una manera coherente y nada traumática de enlazar la ciudad con la naturaleza que la rodea. Ya en el XIX, el Infante don Francisco de Paula, a quien Fernando VII había cedido en usufructo, en 1830, la Montaña del Príncipe Pío, permitía que fuese visitada por el público. Ésta se convirtió en uno de los paseos más concurridos de la capital gracias a los desvelos del Infante que mejoró sus jardines y bosquetes con fuentes, estatuas, grutas... y mandó reconstruir sus edificios al arquitecto Juan Antonio Cuervo ${ }^{29}$. En el reinado de Isabel II el público seguía

las caballerizas del Retiro, frente de la fuente del lado de San Fermín, causando notable fealdad; en ninguna parte mejor se puede dar esta comodidad... Encima del pórtico hay un terrado donde puede subir cómodamente el pueblo a gozar del aire, con la vista del Paseo; y se pueden colocar coros de música en días señalados: al piso de las plazas del pórtico, y del Paseo, se pueden plantar bojes que hagan una hermosa vista a modo de jardín y detrás... hacer un hermoso plantío simétrico de laureles que harán en todos tiempos hermosa vista con los bojes por su perpetuo verdor; y queda un lugar digno en el centro de la plaza, donde se puede colocar la estatua ecuestre del Rey N. S...». Cfr. nota 23.

${ }^{26}$ Existe una Real Orden de 25 de julio de 1773 donde el rey define el fin primordial del Jardín Botánico y subraya su función ornamental para la ciudad. Añón Feliú, Carmen: «Noticias sobre los Reales Jardines Botánicos de Migas Calientes y el Prado», Anales del Instituto de Estudios Madrileños, 1984, p. 112.

${ }_{27}$ Carmen Ariza transcribe en el primer artículo citado en nota 20 (p. 150) el Aviso al público para el paseo a pie en los jardines del Real Retiro, 12 de mayo de 1767.

28 Ariza, Carmen: «La creación de las Escuelas de jardinería durante los siglos XVIII y XIX», Reales Sitios, n. ${ }^{\circ} 89,1986$, pp. 29-36.

${ }^{29}$ Ariza, Carmen: «La jardinería de los Reales Sitios en el Madrid fernandino», op. cit., p. 52. 
pudiendo acceder al Retiro y, previo pago de una entrada, incluso al Reservado; el Estanque Grande y el resto del Retiro eran de libre acceso, salvo cuando fuese a ser utilizado por la familia real. En esta época es cuando se instaló el Museo de Artillería en el ala septentrional del Patio de Fiestas y el Arquitecto Mayor de Palacio, Narciso Pascual y Colomer restauró el Monasterio de los Jerónimos y el Observatorio Astronómico ${ }^{30}$. Cada vez se potenciarán más las actividades públicas en los parques, hasta que en 1868, tras la revolución que derroca a Isabel II, el Retiro pasa a ser propiedad del pueblo de Madrid y a llamarse el «Parque de Madrid». Por otra parte, a mediados del siglo XIX se aprovechaban los jardines de las propiedades reales para acontecimientos que fomentasen el progreso del país, como fue el caso de la celebración en 1857 de la Exposición Nacional Agrícola, en la Montaña del Príncipe Pío, que formaba parte de la Posesión de la Real Florida. El pabellón central de dicha exposición se levantó en estilo árabe y se rodeó de otros pabellones, galerías, estanques y jardines. Por estas fechas también se podía visitar el Casino de la Reina, previa compra de pases válidos para seis personas ${ }^{31}$, y de manera más restringida, algunos distinguidos personajes accedían a las estancias y jardines de la Posesión de Vista Alegre.

Este progresivo afianzamiento de los espacios de recreo público en detrimento de los particulares, queda perfectamente reflejado en los asuntos que, desde fines del siglo XVIII, fueron propuestos a los estudiantes de arquitectura en los exámenes finales de carrera, en los que había que demostrar una determinada aptitud profesional. Entre los temas que debían incluir zonas de esparcimiento, el más socorrido fue, sin duda, el de las casas de campo, destinadas normalmente a particulares. No obstante, existen ciertas diferencias relacionadas con la generalidad o especificidad del enunciado de dicho asunto: así, en 1798, el alumno Juan Antonio Pagola tuvo que proyectar una «Casa de recreo para un Príncipe», y, en 1800, Juan Francisco Rodríguez hubo de realizar una "Casa de Campo para el Rey cuando va a cazar», es decir, se insiste en el carácter privado y hasta personal de estos espacios; posteriormente, la propuesta se vuelve mucho más genérica, limitándose al simple dictado de «Casa de Campo», y, finalmente, se presenta en combinación con otras tipologías arquitectónicas ${ }^{32}$. En cualquier caso, proyectos como éstos, provistos de áreas de recreo para disfrute particular, dieron paso, en las pruebas de pensado, a otros temas plenamente imbuidos ya de una vocación pública; es el caso del magnífico proyecto de Vicente Miranda para un «Jardín de recreo público», de 1853, en el que nos detendremos en un siguiente artículo, y del no menos espectacular «Jardín Zoológico» de Eduardo García Pérez, presentado al año siguiente ${ }^{33}$. Sin embargo, fueron los ejercicios de repente, en esta época

\footnotetext{
30 Ariza, Carmen: «En época de Isabel II, creación y mejoras de los jardines madrileños pertenecientes a la corona», Reales Sitios, n. ${ }^{\circ} 88,1986$, p. 31.

31 A.G.P., sig. 6.112: «Entrada al Casino de la Reina. Permiso para seis personas, excepto cuando SS. MM. y AA. se hallan en ella», 1845 .

${ }^{32}$ El alumno José Pérez Garchitorena desarrolló, en 1845, un «Teatro y Casa de Campo». Un año después, su compañero Juan Blas de Hormaechea tuvo que proyectar una «Casa de Campo y Ateneo», es decir, una tipología privada se combina con otras de carácter público. Archivo de la Academia de San Fernando: Catálogo de las obras de profesores de Arquitectura aprobados de Maestros Arquitectos de 1793 a 1855; sign. 155/3.

33 Gabinete de dibujos de la Academia de San Fernando, planos A-47 a A-50. Esta fechado el 14 de abril de 1854 . A pesar de encontrarse sumamente deteriorado, el proyecto no ha perdido un ápice de grandiosidad. El parque incluye dependencias para toda clase de animales, numerosas zonas ajardinadas y varios estanques para las «fieras del mar». Téngase en cuenta que en aquella época los zoológicos se entendían, no sólo como vitrinas de exposición de animales, sino también como recintos provistos de amplias zonas verdes y arbolado en los que, además de pasear, podrían contemplarse actividades lúdicas de muy diversa índole. Aunque la costumbre de reunir animales exóticos es anterior al siglo XIX (ya en la
} 
autónomos temáticamente y posteriores a los de pensado ${ }^{34}$, los que más se prestaron a un desarrollo de este tipo de asuntos; lógicamente, las pocas horas disponibles para realizar esta prueba impedían el desarrollo de programas amplios, ciñéndose en consecuencia a piezas arquitectónicas de pequeña entidad que, por lo que a nosotros atañe, se correspondían con puertas de acceso a jardines, pórticos, cenadores, fuentes, galerías y similares. En este caso, el compromiso con lo público parece haber sido anterior; en una fecha tan temprana como 1803, la prueba de repente del alumno-arquitecto Manuel Ángel de Chávarri consistió en pergeñar un «Pórtico de recreo público» ${ }^{35}$. Aparte de estas pruebas de capacitación profesional, la Academia promovió la celebración de concursos generales de arquitectura en los que también se propusieron temas de esta naturaleza ${ }^{36}$.

Pero, ¿se acomodaba el entonces vigente sistema de enseñanza de la arquitectura a la realización de este tipo de proyectos por parte del alumnado? Evidentemente, si de lo que se trataba era de hacer una puerta, un cenador o una fuente con destino a un paseo o a un espacio ajardi-

Casa de Campo y en Aranjuez los monarcas se complacían en poder mostrar curiosos animales como elefantes y cebras desde siglos anteriores), recordemos que el primer zoológico que se fundó con ciertas miras sistemáticas fue la Casa de Fieras del Retiro, aunque su función primordial era entretener a los niños de la realeza. Tuvo su origen en el reinado de Fernando VII, que situó los osos en la Montaña Artificial y creó una edificación con jaulas para los felinos. Isabel II adecentaría este lugar ampliándolo para albergar también aves y ganado. En 1860, el director del Real Jardín Botánico, Mariano de la Paz Graells, ubicó un zoológico dentro del recinto de dicho jardín. Además es de resaltar que esta nueva zona del Botánico fue trazada siguiendo un diseño paisajista, con un lago de contornos irregulares alrededor del cual pacían los animales dentro de un cercado, como se puede apreciar en los grabados de la guía de visita del Jardín Botánico de la época (Paz Graells, Mariano de la: El Jardín Botánico y Zoológico de Madrid. Paseo instructivo y recreativo para todos, Madrid, Imprenta de Alejandro Gómez Fuentenebro, 1864). El título de esta guía nos da las claves del espíritu de la época: la intención instructiva es lo principal, pero se combina con el aspecto recreativo del público a quienes van dirigidos estos espacios de esparcimiento y ciencia.

${ }^{34}$ Hasta que la Escuela especial de Arquitectura dispuso de un Reglamento específico en 1850, la obtención del título de Arquitecto estuvo sujeta al tradicional sistema pensado-repente, aparte de una prueba teórica final en la que el aspirante debía responder a una serie de preguntas — de índole matemática básicamente - formuladas por el tribunal; primero se verificaba la prueba de pensado, consistente en desarrollar lo más detalladamente posible un determinado asunto, contando para ello con un periodo de tiempo más o menos dilatado; unos meses después se abordaba el ejercicio de repen$t e$, en el que, disponiendo únicamente de unas horas y trabajando sobre un tema distinto al que había desarrollado en la prueba anterior, el futuro arquitecto tenía que demostrar su pericia mediante esbozos; finalmente, debía superar satisfactoriamente las preguntas del tribunal. Una vez que entró en vigor el referido Reglamento, aprobado por R.O. de 8 de enero de 1850, el procedimiento varió; aun manteniéndose en esencia el binomio pensado-repente, el nuevo sistema prescribía, en primer lugar, el tanteo de un asunto sacado a suerte, aunque siempre relacionado con edificios de segundo y tercer orden, o con partes principales de los de primer orden, contando para ello con un tiempo de seis horas; seguidamente, se daban dos meses para desarrollar y poner en limpio el mismo asunto, debiendo ajustarse el aspirante al bosquejo inicial ya que luego serían cotejados ambos ejercicios. Sobre el Reglamento de 1850, cfr. Colección de las leyes, decretos y declaraciones de las Cortes, y de los reales decretos, órdenes, resoluciones y reglamentos generales expedidos por los respectivos ministerios. Imprenta Nacional; tomo XLIX (1850); disposición n. ${ }^{\circ}$ 16; pp. 17-32.

${ }^{35}$ Fechado el 4 de julio de 1803, el ejercicio incluye planta, alzado y sección. El pórtico o galería consta de un cuerpo central adintelado, de orden toscano, al que flanquean dos alas longitudinales formuladas mediante sendas arquerías de medio punto cuyos huecos se cierran con rejería (Gabinete de dibujos de la Academia de San Fernando, plano A-3548).

${ }^{36}$ Convocados con cierta periodicidad entre 1753 y 1831 , estos concursos dieron entrada frecuentemente al asunto estrella de las casas de campo, destinadas igualmente a particulares (reyes, «grandes señores», «personas distinguidas»...); así ocurrió en las pruebas de pensado (modalidad de 1. ${ }^{a}$ Clase) de 1781 y 1784, en la de pensado (modalidad de 2. ${ }^{a}$ Clase) de 1790 , y en la de repente (modalidad de $1 .{ }^{a}$ Clase) de 1793 . Es de destacar el proyecto de Casa de campo de Juan Antonio Cuervo, premiado en segundo lugar en el concurso de 1784, que cuenta con interesantes jardines de formulación geométrica y simétrica (característica de los ejemplares franceses), además de cenadores con paseos a cubierto, cascadas y zonas boscosas; los parterres imitan, según parece, motivos vegetales tomados de los modelos de Mollet y Dezallier d'Argenville. (Cfr. VV.AA.: Hacia una nueva arquitectura. Premios generales de arquitectura de la Real Academia..., op. cit., pp. 114-117). Por lo demás, aparte de las casas de campo, una de las pruebas de repente del concurso de 1799, concretamente la de la modalidad de $2 .{ }^{a}$ Clase, proponía «Trazar una puerta dórica para entrada de un jardin». 
nado, parece lógico que así fuera. Sin embargo, cabe dudarlo cuando lo que se pedía era el trazado de un jardín o un parque, empresa que, en principio, escapaba al dominio de la arquitectura propiamente dicha, aun cuando la existencia de jardines dependía muchas veces de su condición de ornamento de los edificios. Baste decir que, como asignatura de pleno derecho, la jardinería no se incorporó a los planes de estudio de la carrera de arquitectura hasta $1957^{37}$. Pero eso no es todo porque, además, nuestra jardinería decimonónica — como la setecentista ${ }^{38}$ — apostó por un proyecto pedagógico independiente, que se concretó en la llamada Escuela Normal de Jardineros Horticultores, fundada en 1847. No obstante, dicho establecimiento, cuya creación contó con el beneplácito y la aquiescencia de la Corona, fue impulsado precisamente por un arquitecto de la talla de Narciso Pascual y Colomer, a la sazón Arquitecto Mayor de Palacio, que además enseñó geometría en el mismo. La Escuela, cuya dirección recayó, eso sí, en un jardinero, concretamente en el francés Francisco Viet, se instaló primero en el Campo del Moro para pasar después (1848) a la Casa de Campo $^{39}$. Los quince artículos del reglamento por el que se regía revelan el carácter fundamentalmente práctico y minoritario de esta enseñanza ${ }^{40}$. Por lo demás, los alumnos de la Escuela han dejado interesantes muestras de su buen hacer en los proyectos fin de carrera $^{41}$. A este centro hay que añadir la creación, en 1855, de la Escuela Central de Agricultura, no tan orientada como la anterior hacia la vertiente ornamental de las plantas. Treinta años después, en 1885, aparecía el Instituto Municipal de Artesanos, que, promovido por el Ayuntamiento madrileño, contaba con una cátedra de Floricultura y Arboricultura. Asimismo, no podemos olvidarnos del Jardín Botánico, en el que se había establecido desde su fundación una cátedra de agricultura. Sin embargo, a diferencia de lo que ocurría en otros países europeos, en España no llegó a cuajar plenamente ninguno de estos establecimientos docentes, lo cual lleva a Carmen Ariza a señalar que «el aprendizaje de esta materia siguió siendo, fundamentalmente,

37. Así quedó estipulado por ley de 20 de julio de 1957 y orden ministerial de 9 de mayo de 1962. La materia denominada «Jardinería y paisaje» aparece como asignatura de $5 .^{\circ}$ curso, formando parte concretamente de la especialidad de Urbanismo, una de las cinco secciones por las que se podía optar en el último año de la carrera. En los planes de 1914 y 1932 encontramos sendas asignaturas, también de $5 .^{\circ}$ año, que, aun teniendo por objeto cuestiones de más amplio alcance, bien pudieron ocuparse también de la jardinería; se trata, en el primer caso, de la formulada como «Trazado, urbanización y saneamiento de poblaciones», y, en el segundo, de la conceptuada como «Urbanología». Junta de Directores de las Escuelas Técnicas Superiores de Arquitectura: Arquitectura. Directrices para los planes de estudio. Antecedentes. Ed. Pron. Madrid, 1992; págs. 39 y ss.

38 El autodidactismo o la pseudoformación en el seno familiar, ambos procedimientos fundados en la práctica, fueron casi los únicos medios de aprender el oficio de jardinero hasta el siglo XVIII. Ya en esa centuria, sabemos por M. ${ }^{a}$ del Carmen Ariza del intento frustrado del francés Jean Baptiste Loinville en relación al establecimiento de una Escuela de Jardinería al servicio de los Borbones, en 1761; según la misma autora, poco después, en 1778, el italiano Giuseppe Lumachi creaba en el Real Sitio del Buen Retiro una Escuela Práctica de Agricultura, también conocida como Escuela Pública de Jardinería, que no tuvo demasiada fortuna. Sobre estas iniciativas cfr. Ariza, «La creación de las Escuelas de jardinería durante los siglos XVIII y XIX», op. cit., págs. 29-31.

39 Ibidem, págs. 33-34.

${ }^{40}$ Cfr. Reglamento para la Escuela Normal de Jardineros Horticultores, que se ha de formar en el Parque del Real Palacio con destino á las posesiones del Patrimonio de S.M., en cumplimiento de la Real orden de 13 de diciembre de 1847. Madrid, 1848. Tal vez el hecho de ser un centro docente con un número de alumnos bastante limitado, así como la implicación directa de la Casa Real en la empresa, sean los argumentos que mejor puedan explicar aspectos un tanto chocantes como el del sueldo anual de 2.400 reales que percibirían los estudiantes «todo el tiempo que permanezcan en la Escuela»; y es que, de hecho, tenían el carácter de «empleados de la Real Casa» (art. 6. ${ }^{\circ}$ ); del mismo modo, «todos los libros e instrumentos que necesiten los alumnos para su instrucción se les facilitarán por cuenta de la Real Casa» (art. $8 .^{\circ}$ ). La duración prescrita para estos estudios, cinco años, puede resultar engañosa si tenemos en cuenta que los conocimientos científicos se limitaban a la aritmética, geometría, delineación, francés, dibujo (de figura, adorno y paisaje, en la Academia de San Fernando), botánica y fisiología vegetal (art. 7. $^{\circ}$. Por lo demás, el artículo 14 fijaba en sólo ocho el número de alumnos de la Escuela.

${ }^{41}$ Cfr. Ariza, «La creación de las Escuelas de jardinería durante los siglos XVIII y XIX», op. cit.; pág. 35. Se describen varios diseños que responden a un mismo tema propuesto en los años 50: «Un proyecto de jardín o más concretamente una casa de campo para el clima de Madrid». 
práctico, heredado de padres a hijos, basado en la improvisación y en la mala copia de lo que venía de fuera...» ${ }^{42}$.

A pesar de lo dicho, en la Escuela de Arquitectura no se relegó del todo el tema de los jardines. Aparte de las nociones básicas que, relacionadas con aspectos del terreno, suministraba una materia como Topografía, el programa de la asignatura de Teoría General de la Composición incluía, tal como estaba estructurado en 1855, un apartado dedicado a las construcciones civiles, en cuya sección de edificios de instrucción pública se habla de las «Escuelas de botánica y jardines botánicos», tratando, entre otros asuntos, la clasificación y distribución de los jardines botánicos, los medios de irrigación, la formulación de entradas y salidas, los estanques para las plantas acuáticas y el estudio de los jardines existentes. Asimismo, en la «cuarta parte», donde se tratan las construcciones privadas, se estudiaban las casas de campo ${ }^{43}$. Aunque más tardío (1870), el programa de Teoría General de la Arquitectura revela un compromiso mucho mayor en este sentido; así, además de no descuidar temas como la belleza en el reino vegetal (color, forma simétrica, etc.), se presta bastante atención a los jardines, cuyo estudio queda englobado bajo el epígrafe «Patios, jardines y fuentes». Y resulta curioso comprobar cómo, efectivamente, se neutraliza la autonomía de los jardines con respecto a la arquitectura, cuando se alude a las «condiciones que han de satisfacer los jardines como partes accesorias de los edificios». Asimismo, se consigna la necesidad del estudio de los diferentes sistemas de trazado de jardines (francés, inglés...), incluyendo las ventajas que presenta cada uno de ellos y las particularidades de los mismos en lo referente a la delineación de calles (inglés), a la situación de estanques y saltos de agua (francés) y al empleo de elementos «que accidentan el terreno y le comunican un aspecto pintoresco» (inglés), para terminar proponiendo el estudio de los ejemplos más importantes de ambas disposiciones. Finalmente, el programa de la asignatura retoma el tema de los jardines al considerarlos como partes accesorias, aunque necesarias, de la distribución de ciertos edificios: cárceles y presidios, hospicios, facultades de medicina, hospitales y centros de salud en general (en estos casos serían una garantía de salubridad), escuelas de bellas artes (el jardín serviría para las prácticas topográficas de los estudios de Arquitectura), edificios administrativos (aquí funcionarían como elementos de realce), palacios arzobispales («huerta-jardín para solaz del prelado y sus familiares»), casas de baños, etc.; en ocasiones, la distribución de esos edificios llega a dar entrada incluso a una habitación particular para el jardinero ${ }^{44}$. Por su parte, Demetrio de los Ríos, profesor de Teoría del Arte, dedicaba a los jardines el último punto de la lección LXII - relativa a la Distribución - del programa de esta asignatura, elaborado en 1870. Allí se ocupaba del arte de la jardinería en general, de su consideración estética, de su dependencia respecto a los edificios, de su necesidad, localización, magnitud, distribución, clases, formas y nomenclatura, de los «jardines-parques» y de los «jardines-patios», así como de sus fuentes, estanques, quioscos, cenadores, estufas, etc. ${ }^{45}$. Por lo demás, la Revista de la Arquitectura Nacional y Extranjera publicaba un artículo anónimo en 1885, en el que su autor plantea la necesidad de un plan de reforma de la enseñanza de la Arquitectura, en virtud del cual los estudios preparatorios

${ }^{42}$ Ibidem; pág. 35. La autora se hace eco de unas palabras de Fernández de los Ríos en las que éste se lamenta de semejante situación, al tiempo que alaba el buen proceder de los países más civilizados de Europa, que «hacían de este arte por sí una profesión que se enseña por verdaderos principios, para formar los que hoy se llaman arquitectos de jardín» (el subrayado es nuestro); op. cit., págs. 35-36.

${ }^{43}$ Cfr. Programas de las diferentes asignaturas que se esplican en la Escuela Especial de Arquitectura con arreglo al nuevo Reglamento aprobado por S.M. en 24 de enero de 1855. Madrid, 1855; pp. 176 y 185.

${ }^{44}$ Cfr. Teoría General de la Arquitectura. Programa de un curso de Teoría del arte arquitectónico, con aplicación a la composición de los edificios. Madrid, 1870; pp. 10, 38-39, 52 y ss.

45 Ríos y Serrano, Demetrio de los: Arquitectura. Teoría del Arte, Invención, Distribución y Decoración. Memoria sobre las fuentes de conocimiento y método de enseñanza, y programa razonado de la indicada asignatura. Madrid, 1870; pág. 79. 
no podrían prescindir de dos materias: Mineralogía y Botánica, y, Fauna y flora artísticas ${ }^{46}$. Es decir, aun no se habla abiertamente de jardinería como asignatura en toda regla; años atrás, Luis Cabello y Aso no había dudado en afirmar que, en lo que se refiere al reino vegetal, «lo que verdaderamente más interesa al arquitecto es la forma exterior de las plantas, su desarrollo, de cuyas flores y frutos debe sacar partido para la composición del ornato» ${ }^{47}$.

Por otra parte, los fondos bibliográficos sobre la materia con que contaba la biblioteca de la Escuela de Arquitectura, pueden dar idea igualmente de los recursos de que disponían los jóvenes aspirantes a arquitecto para desarrollar proyectos de esta naturaleza. Lógicamente, huelga decir que la biblioteca de la Escuela Normal de Jardineros-Horticultores estaba bien surtida a este respecto ${ }^{48}$; y lo mismo puede decirse de la biblioteca del Jardín Botánico, donde los tratados de la ciencia «no bajan —-según Pascual Madoz- de 2.500 volúmenes» ${ }^{49}$. A través de la cuenta que la Escuela de Arquitectura tenía abierta en la Librería de Casimiro Monier, tenemos constancia de que, en 1847, fue adquirido el libro de Karoff, Jardins de France et d'Angleterr $^{50}$. Aparte de las estampas suministradas por la firma «Juan Bautista Stampa/Los Suizos», sabemos, gracias a los datos aportados por un Índice general de libros de 1857, que en la biblioteca de la Escuela de Arquitectura existían también los siguientes títulos: Descripción de las plantas que demostró en las lecciones públicas del año de 1801, de Antonio José Cavanilles; Gates, Lodges, Palisadings and Iron Work of the Royal Parks (Dessings of ornamental); Construction, plans et decorations des jardins de France, de J. Ch. Krafftt; The Magesty's pavillon in Buckingam garden, de Lewis Grunner; Diverse maniere de adornare i cammini, de G. Battista Piranesi; The decorations of the Garden-Pavillon in the grounds of Buckingam Palace, de Lewis Grunner; además de los estudios, colecciones y cursos de paisaje de los franceses Hubert, Jacottet, Richebois, Calame, Coignet, Ferogio y Tirpenne ${ }^{51}$. Así pues, la primacía de las bibliografías francesa e inglesa en esta materia resulta verdaderamente abrumadora; no en vano eran Francia e Inglaterra los países que ostentaban la paternidad de los dos modelos de jardín más difundidos.

Ciñámonos ya a los proyectos. La primera pieza que integra nuestro ideal jardín de las delicias es un pórtico; se corresponde con el proyecto ideado por el murciano José María de Vivar en 1835 para la prueba de repente del examen final que, de superarlo, daba derecho al título de Arquitecto. Conforme prescribe la R.O. de 29 de julio de 1801, el aspirante ejecutó en primer lugar el ejercicio de pensado, que desarrollaba el asunto de una Casa o Palacio destinado a Academia de Bellas Artes; los planos se acompañaban de un informe facultativo y del cálculo de costes. Eligirá, entre una terna de propuestas, el tema de su prueba de repente, que consistió en «un pórtico espacioso para un paseo público de una capital, en donde puedan refugiarse y pasear cómodamente las personas en ocasión de lluvia repentina, el cual dé ingreso a café, botillería y mesas de juego público» ${ }^{52}$ (Fig. 1). Como puede advertirse, se insiste mucho en el carác-

\footnotetext{
${ }^{46}$ Cfr. Anónimo: «Los estudios del arte arquitectónico en España», en Revista de la Arquitectura Nacional y Extranjera. Madrid, 31 de enero de 1885; pp. 3-8.

${ }^{47}$ Cabello y Aso, Luis: El arquitecto. Su misión, su educación, sus conocimientos y enseñanza. Madrid, 1869; pág. 17. Consideraba indispensable entre los estudios especiales una materia de «Dibujo de la flora ornamental y composición del ornato», en la que se estudiasen las flores y las plantas reducidas a forma arquitectural.

${ }^{48}$ Sobre el alcance de los fondos de este establecimiento en 1849, cfr. Ariza, «La creación de las Escuelas de jardinería durante los siglos XVIII y XIX», op. cit., pág. 34 .

${ }^{49}$ Madoz, Madrid. Audiencia, Provincia, Intendencia, Vicaría, Partido y Villa, op. cit, , pág. 391.

50 Archivo de la Real Academia de Bellas Artes de San Fernando. Legajo 32-16/1.

51 Archivo de la Real Academia de Bellas Artes de San Fernando: «Índice general de los libros que contiene la Biblioteca de la Escuela especial de Arquitectura. Madrid, 21 de agosto de 1857». Legajo 63-8/5.

52 Archivo de la Real Academia de Bellas Artes de San Fernando. Legajo 4-5/2. El enunciado completo del programa queda expresado también en el plano correspondiente, conservado en el Gabinete de Dibujos de la Academia, sig. A-3557.
} 
ter público, tanto del conjunto en sí, como de los elementos que lo integran. Se trata de un edificio de una sola planta, acusada horizontalidad y filiación estética clasicista, que consta de un amplio cuerpo central precedido de escalinata y rematado en sus extremos por dos pequeñas alas que se adelantan ligeramente en planta respecto a él; cuatro parejas de grandes pilares de sección cuadrada, con edículos centrales en cada una de sus caras - salvo una de los extremos-, dividen este espacio central destinado a paseo en tres tramos que, poblados de columnas dóricas, se formulan a modo de salas hipóstilas. A diferencia de la fachada delantera, completamente abierta, la trasera se cierra con un muro de fábrica que, calado por multitud de vanos, se continúa por todo el perímetro de las dependencias laterales. En éstas es donde se ubican el café y las distintas salas de juegos. Sencillos parterres rectangulares se disponen en la parte trasera. José María de Vivar fue aprobado de maestro arquitecto en junta ordinaria de 23 de agosto de $1835^{53}$.

Analizaremos ahora una serie de proyectos diversos sobre un mismo tema, las puertas de acceso a jardines o parques públicos de diversa índole: jardines de recreo y jardines botánicos; temática propuesta por la Academia numerosas veces como «prueba de repente», quizás por el carácter abarcable del mismo. De todas maneras, se trata de un tema de clara vocación urbana, ya que las puertas son necesarias en los jardines no sólo por su finalidad específica, sino también como motivo ornamental, de amenidad de cara al paseante que disfruta de su ciudad. Incluso, a veces, presentan un porte monumental que las podría convertir en un hito urbano al igual que sus hermanas, las puertas de ciudad. Por ello dedicaremos lo que resta de artículo a estudiar estos proyectos y compararlos con los casos reales más representativos que existían en Madrid, a manera de acceso simbólico a nuestro jardín de las delicias y en un próximo artículo analizaremos otros elementos característicos de los ámbitos de recreo público decimonónicos, también mediante el método de comparación entre proyectos ideales y construidos.

El catalán de Montroy (Tarragona) Juan Rom y Vidiella, aprobado de maestro arquitecto el 25 de mayo de $1845^{54}$, había estudiado en la Academia de Barcelona pero tuvo que examinarse en Madrid para obtener la titulación. Habiendo hecho para la prueba de pensado un proyecto de Museo dedicado a la enseñanza de las ciencias..., la de repente consistió en una magnífica entrada de Jardín Público, con dos alas de galerías en arcos donde habrá sus bancos para descanso y para cubrirse de alguna lluvia, colocando dos estancias para guardas. Planta, alzado y un corte $^{55}$ (Fig. 2). Un cuerpo central de planta cuadrada y cubierta cupuliforme, que determina la existencia de cuatro potentes machones angulares, se ve flanqueado por dos galerías cuyos lados largos se formulan a base de arquerías de medio punto sobre pilares, quedando cerrados cada uno de sus siete vanos por sencillas verjas de hierro. Las dependencias extremas que rematan el conjunto incluyen dos recintos carentes de comunicación entre sí, uno de los cuales rebasa completamente la línea de fachada trasera de la galería adyacente. El cuerpo central se realza notablemente a través de su fachada principal, en la que un par de columnas exentas a cada lado sostienen una especie de romanato cuya parte central presenta una solución decorativa en abanico. El conjunto guarda una simetría estricta y revela un seguimiento evidente de patrones estéticos y compositivos de raigambre clásica.

\footnotetext{
${ }^{53}$ Archivo de la Real Academia de Bellas Artes de San Fernando: Registro de los maestros arquitectos aprobados por la Real Academia de Nobles Artes de San Fernando (...) desde el 28 de agosto de 1816. Sign. 3/154; fol. 20v. ${ }^{\circ}$, n. ${ }^{\circ} 173$.

${ }^{54}$ Registro de los maestros arquitectos aprobados por la Real Academia de Nobles Artes de San Fernando (...), op. cit; fol. $32 \mathrm{r}^{\circ}, \mathrm{n}^{\circ} 286$.

55 Archivo de la Real Academia de Bellas Artes de San Fernando. Legajo 12-4/2. Los dos programas desestimados fueron: «una escalera de caracol de piedra...» $\mathrm{y}$ «una capilla para una universidad...». El plano se encuentra en el Gabinete de Dibujos de la Academia, sign. A-3516.
} 
El asunto de la prueba de repente del santanderino Manuel Gutiérrez, ejercicio que data del 11 de agosto de 1845, rezaba así: portada adornada para entrar al Jardín botánico, y a los lados dos pabellones para habitación de los porteros principales. Se demostrará en planta, fachada y una sección ${ }^{56}$ (Fig. 3). El proyecto de Gutiérrez, que había sido discípulo de Antonio de Zabaleta, es el típico diseño académico dotado de una simetría estricta y una jerarquía manifiesta en la disposición de los distintos elementos que lo conforman. El motivo principal, la puerta, llega a convertirse en un pretexto para concebir finalmente una obra mucho más ambiciosa, al menos en planta, en la que las casas de los porteros reciben probablemente mayor atención de la debida; tan es así, que la única leyenda explicativa que se incluye en el plano tiene que ver con las distintas estancias que constituyen esas viviendas (sala, antesala, alcoba, pasillo, cocina y despensa). Pero, en alzado, a diferencia del proyecto anterior y del que viene a continuación, la puerta recaba para sí todo el protagonismo del conjunto, puesto que las dependencias auxiliares quedan relegadas a la parte trasera, evitando de este modo que compitan con ella, cosa que ocurriría si se alinearan con su fachada; el resultado, por tanto, es una solución en profundidad y no en longitud. Monumentalizada por medio de los dos pares de columnas sobre pedestales que la flanquean, al tiempo que sostienen un entablamento, la puerta se realza también por mor de su altura, que supera con creces la del resto de los elementos del conjunto. Manuel Gutiérrez fue aprobado de maestro arquitecto el 14 de septiembre de 1845.

Por su parte, el granadino Antonio López León fechaba el 29 de octubre de 1845 su prueba de repente, después de haber entregado en agosto la de pensado, en la que diseñó un Palacio para la Audiencia territorial de Granada. Como tema de aquélla eligió una glorieta para entrada de un Jardín Público, con grupos laterales para habitaciones de guardas. Planta, alzado y un corte ${ }^{57}$ (Fig. 4). Similar al de Rom y Vidiella, aunque aquí prescindiendo de las galerías, este proyecto presenta bastante más elaboradas las estancias de los vigilantes, al menos en lo que se refiere a la distribución interior en planta. El único enlace de estas últimas con la glorieta propiamente dicha consiste en dos sencillos parapetos alineados con la fachada de los tres edificios. El monumental vestíbulo del jardín es de planta cuadrada y, como en el caso del diseño de Juan Rom, cuenta con cuatro poderosos machones en los ángulos, que aquí, sin embargo, no se explican del todo bien, puesto que únicamente soportan una ligera bóveda esquifada de hierro y cristal. También se repite la solución de las columnas pareadas - en este caso sobre pedestales - flanqueando la puerta de ingreso, cuyo vano presenta aquí remate semicircular y no adintelado. López León, que, temeroso por no haber podido completar la otra media planta, ruega por escrito al tribunal en el mismo plano que sepa dispensarle esa falta $-\mathrm{y}$ es que la parte inconclusa «es idéntica a la otra»-, fue aprobado de maestro arquitecto en Junta ordinaria de 25 de enero de $1846^{58}$.

Por las mismas fechas debió titularse el madrileño Jacinto San Martín, que no parece haber tenido demasiada fortuna en estas lides; fue reprobado en dos convocatorias anteriores, viéndose obligado a repetir las pruebas de pensado y de repente al presentarse a examen por tercera vez, cosa que hizo poco tiempo después. Fue en este tercer intento cuando proyectó, en el ejercicio de

${ }^{56}$ Archivo de la Real Academia de Bellas Artes de San Fernando. Legajo 12-5/2. Los temas no elegidos fueron: «una casa de ayuntamiento...» y «un gran salón con destino a armería...». Por su parte, la prueba de pensado consistió en el proyecto de un «colegio para todas las carreras y con destino a esta Corte...», fechado el 15 de julio de 1845. El plano de la «puerta» se corresponde con la sign. A-37 del Gabinete de Dibujos de la Academia.

57 Archivo de la Real Academia de Bellas Artes de San Fernando. Legajo 13-3/2. Las otras dos opciones fueron: «una Sala Capitular para una catedral...»y «una Sala de Juntas pública...». El plano en cuestión se encuentra en el Gabinete de Dibujos de la Academia bajo la sign. A-3517.

${ }^{58}$ Registro de los maestros arquitectos aprobados por la Real Academia de Nobles Artes de San Fernando (...), op. cit. nota 55 ; fol. $36 v^{\circ}$, n. $^{\circ} 309$. 

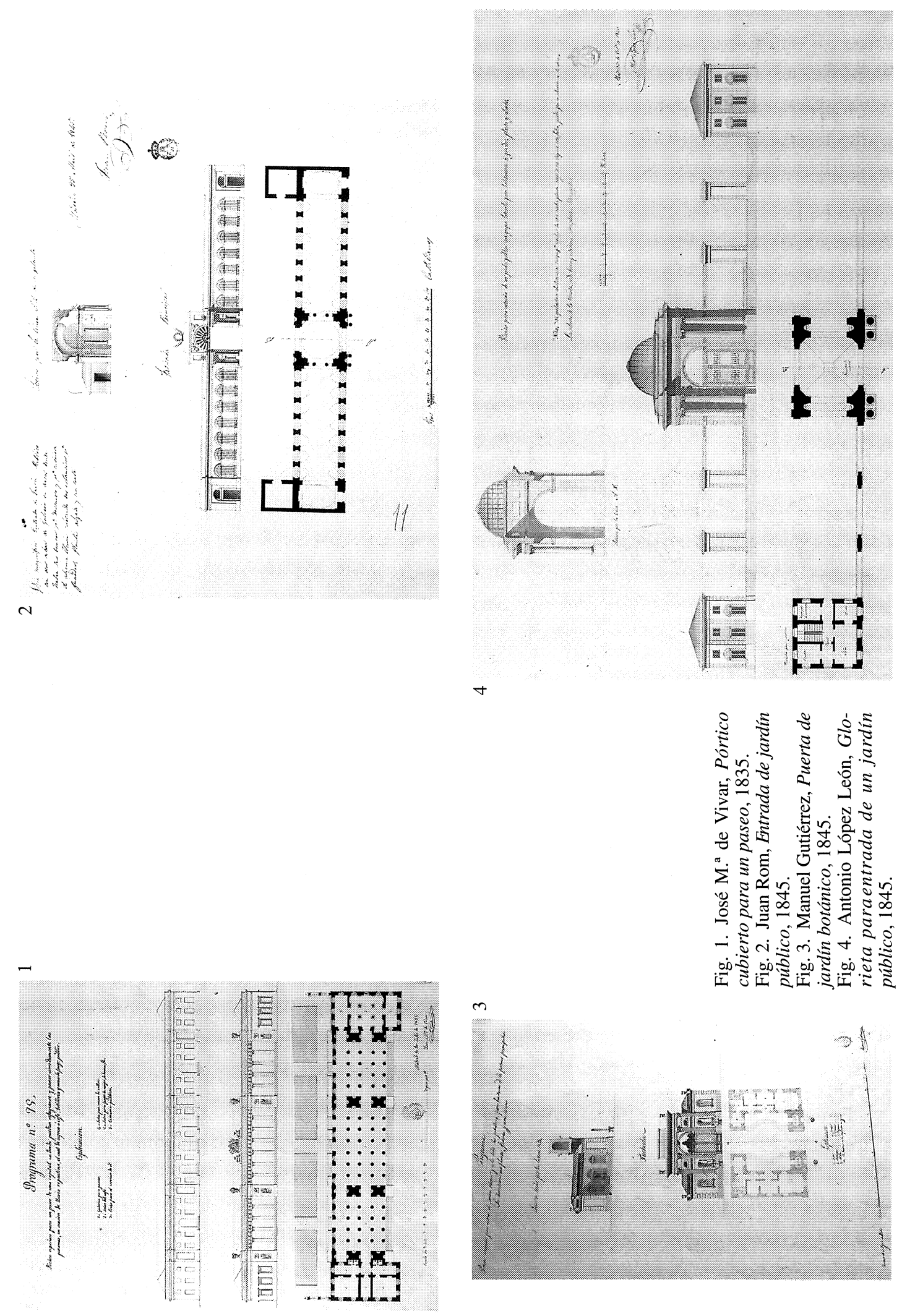

$\checkmark$
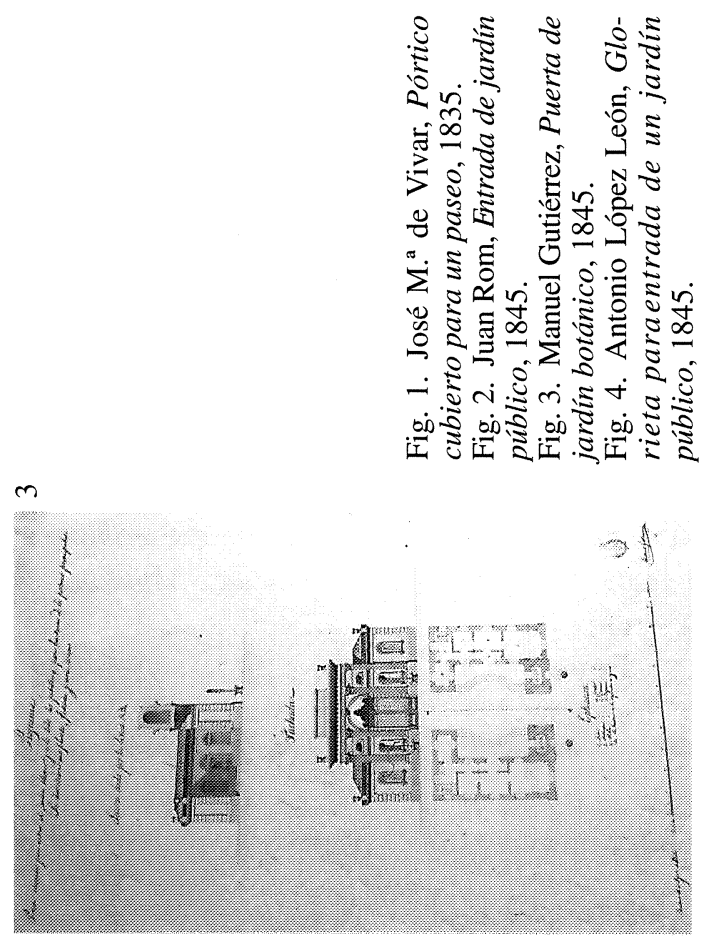
repente (27-X-1846), una portada adornada para entrar al Jardín botánico, y a los lados dos pabellones para habitaciones de los porteros principales ${ }^{59}$ (Fig. 5), esto es, el mismo asunto que había desarrollado un año antes Manuel Gutiérrez. En este caso retomamos la simetría estricta de aquel proyecto, pero aparece una diferencia sustancial: San Martín, como ya hicieran Juan Rom y Antonio López en sus respectivos diseños, dispone longitudinalmente los distintos elementos que prescribe el tema. Siendo rigurosos, habría que decir que cada uno de esos elementos (dos dependencias cuadradas y dos módulos de puerta) tiene una existencia autónoma con respecto a los demás; y es que son simples verjas de hierro, y no muros de fábrica, las que asumen la condición de nexos de unión más aparentes que reales. Las estancias de los guardas son meros espacios cuadrangulares completamente diáfanos, que han perdido la rica compartimentación de sus homólogas del proyecto de Gutiérrez; en fachada, sólo los frontones curvos coronados por un motivo decorativo les reportan cierta animación. En cuanto a las dos piezas que delimitan la puerta, son auténticas esculturas exentas; su esquema compositivo es el mismo: dos columnas sobre pedestal único que sostienen entablamento y copete ornamental, y enmarcan una figura escultórica.

Podemos buscar semejanzas, bien formales o bien intencionales, de estas arquitecturas de papel que reflejan las inquietudes de los estudiantes, con la realidad de los espacios libres que se estaban construyendo en el Madrid de la época. Hay que recordar que, desde el final de la Guerra de Independencia, se estaba afianzando el estilo de jardín paisajista que había visto sus primeras manifestaciones en nuestro suelo a finales del siglo XVIII. El jardín paisajista naciera bajo la intuición de que la existencia de una naturaleza libre es necesaria para contrarrestar la presencia del hombre y su modificación del paisaje, por el deseo de mantener una libertad en el espacio y en la tierra como símbolo de su propia libertad y por un culto humanista del individuo que exaltaba los valores de la soledad y el retiro. Por ello comenzó siendo el jardín propio de las grandes fincas suburbanas, refugio de los avatares de la Corte; pero en ese anhelo y añoranza de la naturaleza primigenea estaba también el germen de la explosión del jardín público en el interior de las ciudades industriales.

Este estilo proliferó pues, en un principio, en los amenos jardines de las villas de recreo y de los palacetes urbanos de la aristocracia y de la burguesía emergente, antes de que se realizasen ámbitos específicos para el recreo público. También se aplicó en las remodelaciones de algún Real Sitio y en la creación del Casino de la Reina y la Posesión Real de Vista Alegre. Aunque esta faceta privada del jardín nos interesa menos en nuestro caso, nos será inevitable en ocasiones referirnos a algunos de estos ejemplos a la búsqueda de analogías. Ya que, por un lado a veces son el único antecedente que existe y seguramente serían conocidos por los alumnos y, por otro lado, si bien el carácter privado de estos ámbitos no permitía el recreo del ciudadano, es evidente que la proliferación de jardines dentro de la ciudad le confiere a ésta y a sus alrededores cierta fisonomía que estaba en concordancia con el espíritu de la época.

Entre 1812 y 1820 se mejora el entorno del embarcadero del Manzanares, plantando alineaciones de árboles en las avenidas de los alrededores; de 1823 a 1833 se plantan árboles en la Ronda desde Santa Bárbara hasta el paseo de Recoletos; se termina la Puerta de Toledo y se

59 Archivo de la Real Academia de Bellas Artes de San Fernando. Legajo 13-6/2. Al elegir el programa de la puerta del Jardín botánico, desechó los siguientes: «una casa-fonda...» y «un monumento público a la memoria del arquitecto Juan de Herrera...». Para la prueba de pensado había ideado «un pequeño teatro...». El plano de la «puerta» está catalogado con la sign. A-39 en el Gabinete de Dibujos de la Academia. 
plantan árboles desde ella hasta el puente del mismo nombre; además se crea el paseo de las Delicias de Isabel II, que parte de la puerta de Recoletos hacia el norte, donde se levantó en 1833 la Fuente del Obelisco de la Castellana, diseñada, como todo el conjunto, por Francisco Javier Mariátegui.

Durante la regencia de María Cristina se transforman los paseos y calles de Madrid en frondosas y arboladas avenidas ${ }^{60}$, plantándose en 1833 los paseos de la Castellana, del Cisne, la Habana, Areneros y el camino de Vallecas. Dos años más tarde le llega el turno a la calle Luchana y paseos contiguos; entre 1836 y 1840 se arbolan las plazas del Rey, de Bilbao y del Progreso y las calles de Atocha y Alcalá. En 1841 se realiza el jardín de la Plaza de Oriente y poco después se plantan las plazas de Santo Domingo, Isabel II, las Cortes, el paseo de Recoletos y el Depósito del Canal.

Durante la época isabelina, a los postulados de ornato y embellecimiento del reformismo ilustrado se superponen los criterios sanitarios de la vegetación, bajo la influencia del urbanismo de Londres y París. Emulando los cementerios franceses se inundan de arbolado los nuestros, se ajardinan numerosas plazas a imitación de los squares londinenses y se trazan un sinfín de bulevares: paseos arbolados con una franja en el centro donde instalar pequeñas construcciones como quioscos, fuentes, marquesinas y bancos. Este mobiliario urbano, de gran importancia en la segunda mitad de siglo, tuvo su origen en el jardín, de cuyos caprichos conserva cierto pintoresquismo. Adquieren los más diversos lenguajes historicistas y se extienden por plazas y calles a la vez que el uso del hierro en la arquitectura ${ }^{61}$. Las nuevas plazas ajardinadas se ordenan, en general, colocando una fuente central y cerrando el ámbito con alineaciones de árboles. Rompe esta sencillez el ajardinamiento de la Plaza de Oriente que busca una marcada monumentalidad a pesar de la acertada utilización de frutales.

Las propuestas de mejoras y reformas urbanas de Mesonero Romanos ${ }^{62}$ contemplan la creación de nuevos jardines, la repoblación de árboles y el ajardinamiento de las plazas. A él se deben muchas de las plantaciones realizadas en esos años, así como la reforma de la plaza Mayor con un trazado en elipse, rodeada de farolas y bancos y con la estatua de Felipe III en el centro.

En 1860 fue aprobado el anteproyecto general de ensanche de Madrid de Carlos M. ${ }^{a}$ de Castro ${ }^{63}$, que proponía extender el Retiro y formar barrios aislados entre sí, rodeados de parques y jardines. Por primera vez se habla de las «zonas verdes» como espacios de salubridad e higiene pública. Sin embargo, no se trataba de una jardinería integrada en el contexto, sino de espacios verdes salpicados arbitrariamente dentro de la trama urbana ${ }^{64}$. Las zonas ajardinadas previstas para el ensanche vieron notablemente mermada su extensión debido a procesos especulativos, pero el proceso de «invasión» de la naturaleza dentro del centro urbano continuaba. En estos años la jardinería urbana se va haciendo más compleja y el sencillo trazado inicial de las plazas ajardinadas se va poblando de arbustos, rosales, setos, flores, caminos sinuosos que forman rom-

${ }^{60}$ Serredi, Lucia: «La jardinería en el paisaje urbano madrileño» en Jardines Clásicos Madrileños, Ayto. de Madrid, 1981, p. 158

${ }^{61}$ Soto Caba, Victoria: «Jardines de la Ilustración y el Romanticismo en España» en Buttlar, A. von: Jardines del Clasicismo y el Romanticismo, el jardín paisajista, ed. Nerea, 1993, p.323.

${ }_{62}$ Inicia sus observaciones en 1835 en Rápida ojeada sobre el estado de la capital y los medios de mejorarla. En su Plan de mejoras generales de Madrid..., Imp. de Agustín Espinosa, 1846, especifica los problemas de la ciudad y sus posibles soluciones y es el primero que ve la posibilidad de realizar un ensanche de la ciudad (cuyo plan será trazado para él por el ingeniero Juan Merlo). Completa sus propuestas en Memoria explicativa del Plano General de Mejoras..., Madrid, 1849.

${ }^{63}$ Castro, C. M. ${ }^{a}$ de: Memoria descriptiva del anteproyecto de ensanche de Madrid, Madrid, 1860. Ed. fcs. con estudio preliminar de Antonio Bonet Correa, C.O.A.M., 1978

${ }^{64}$ Serredi, «La jardinería en el paisaje urbano madrileño», op. cit., p. 159. 
pecabezas de macizos entre los que aparecen numerosos bancos, pues la función principal de estos recintos era poder disfrutar del aislamiento que produce el jardín dentro de la maraña de la ciudad. Es el auge del jardín conocido por el nombre de estilo isabelino. Hay que tener en cuenta que, aunque las realizaciones fueron muchas, también se quedaron en el tintero muchos proyectos pensados para reformar o adornar paseos y plazas ${ }^{65}$, que habrían amenizado aún más la ciudad.

Fueron decisivas, aunque no llegaron a ejecutarse, las propuestas realizadas por Fernández de los Ríos desde el exilio, para la creación de nuevos parques en Madrid, pero ya tras la revolución de $1868^{66}$. Proponía, desde postulados higienistas y siguiendo un modelo haussmanniano, tres fases de reformas para la ciudad que se fundamentaban en actuaciones sobre las zonas verdes. Sus deseos eran ajardinar las plazas y aterrazar todo el barrio de Palacio; hacer de la Casa de Campo y otras posesiones reales una especie de Bois de Boulogne de manera que se articulase el centro de la ciudad con los alrededores; unir el Prado con el Parque del Retiro y ampliar la extensión de éste último a más del doble; convertir en alamedas y jardines las orillas del Manzanares... Hay que añadir que estas reformas conllevaban reformas de carácter ideológico, cívicas, sociales y políticas ${ }^{67}$, es decir, el sustrato ideológico que siempre estaba latente en las reformas relacionadas con los parques y en la misma aparición del jardín paisajista.

En 1868, como habíamos comentado, el Retiro pasa a ser propiedad de los madrileños y en los años siguientes se procede al ajardinamiento de numerosas plazas, tanto del casco antiguo como en el ensanche, se fundan numerosos jardines públicos de recreo y la Castellana logra su máximo esplendor con sus palacetes rodeados de jardines. En el plano de Ibáñez Ibero de 1872-74 se puede comprobar la difusión alcanzada por el estilo isabelino tanto en jardines privados, como en zonas públicas en una época en que Madrid era una verdadera ciudad verde.

Pasaremos ahora a comentar algunos proyectos que forman parte de jardines, parques o paseos construidos en la realidad que, o bien pudieron servir de inspiración, o bien tienen puntos en común, con los proyectos académicos que hemos visto. Comenzaremos con el tema que más abunda en nuestros ejemplos, las puertas de jardín. En 1845 tres alumnos realizaron como prueba de repente para la obteción de su título este tema, dos de ellas serían la entrada de un jardín público y la tercera el acceso a un jardín botánico. Resulta curioso constatar la enorme influencia vilanovina que presentan todas ellas a pesar de estar inmersas en pleno período de la arquitectura isabelina, ya no tan deudora de la herencia de Villanueva. Sin embargo no es de extrañar esta influencia, pues en aquella arquitectura que se consideraba de carácter representativo sí se daba una continuidad con el neoclasicismo, y una puerta de jardín, al igual que si se tratase de una puerta de ciudad, debía de considerarse lo suficientemente representativa como para seguir esta línea. Además, las referencias a Villanueva no son tanto lingüísticas, como de índole espacial; en efecto, las tres repiten el carácter estancial que puede tener una puerta, alejándose del mero fachadismo, como ocurría en la emblemática «Puerta de Murillo» del Real Jardín Botánico. Ésta seguía una depurada línea clásica, pero su concepción espacial era totalmente novedosa respecto a lo que solían ser las puertas de ciudad o de jardín, y ponía de relieve las dos fuentes de formación que había recibido el arquitecto: la antigüedad clásica y su estudio de los

${ }^{65}$ Cfr. Ariza, Carmen: «Proyectos no realizados en los jardines madrileños decimonónicos», Anales del Instituto de Estudios Madrileños, 1986, pp. 87-97.

${ }^{66}$ Fernández de los Ríos, Ángel: El futuro Madrid. Paseos mentales por la capital de España, tal cual es y tal cual debe dejarla transformada la Revolución, Madrid, 1868. Ed. fcs. con estudio preliminar de Antonio Bonet Correa, Los libros de la Frontera, Barcelona, 1975.

67 Soto Caba, Victoria: «El jardín madrileño en el siglo XIX: propuesta y realidad», Anales del Instituto de Estudios Madrileños, 1982, p. 113. En este artículo, la autora analiza en profundidad todas las propuestas jardineras realizadas por Fernández de los Ríos. 
monumentos árabes en España, en los que la puerta es un ámbito espacial complejo y no tan sólo un símbolo. Asimismo, el proyecto de Antonio López León, salvando la verja y los edificios laterales del conjunto, nos recuerda muchísimo un proyecto de 1789 de una Puerta de Manuel Machuca (Fig. 6), que también presenta dicha concepción estancial, pero si cabe más clasicista, por su aspecto de templete y la planta centralizada permeable por los cuatro lados. Se remata con una cúpula y los vanos son adintelados con columnas in antis. Además, este proyecto se trataba de un diseño para la «entrada pública» de los jardines del Buen Retiro ${ }^{68}$. En el caso de nuestro alumno las columnas son pareadas y la cúpula, más moderna, es un lucernario en hierro y cristal.

$\mathrm{Al}$ año siguiente, 1846, vuelve a aparecer como tema de examen una Puerta de un Jardín Botánico. Esta vez, el alumno, Jacinto San Martín, recurre a una referencia que se descubre de inmediato: la puerta del Casino de la Reina (Fig. 7) con sus dos elementos laterales y vano libre con verja de hierro, dichos laterales con marcado carácter vertical, formados por sendas columnas pareadas sobre pedestales y rematadas con porciones de entablamento que sostienen sendas figuras. El Casino de la Reina ${ }^{69}$ era una Posesión Real sita junto al portillo de Embajadores, que había sido regalada por el Ayuntamiento de Madrid a la reina Isabel de Braganza en 1817. Ésta la había reformado adaptándola al gusto paisajista y construyendo en su interior caprichos y temas típicos de este estilo. La Puerta principal data de 1820 y resuelve la necesidad de dar una entrada monumental al Real Sitio desde el Paseo de Embajadores. Actualmente, y ya desde 1885, se encuentra en la puerta del Retiro que da a la plaza de la Independencia. El Real Casino dejó de ser propiedad privada en 1867, cuando Isabel II lo cedió para instalar el Museo Arqueológico Nacional, que sería inaugurado en 1871, ya por Amadeo I. La puerta del Casino se inspiraba a su vez en la puerta del Embarcadero del Jardín del Príncipe en Aranjuez, realizada también por Villanueva en 1784; las tres puertas (la del Casino, la de Aranjuez y la del alumno de la Academia) siguen exactamente el mismo esquema compositivo y persiguen la misma intencionalidad meramente decorativa, prescindiendo en este caso de la concepción espacial de las anteriormente comentadas.

También con el mismo carácter monumental que las Puertas de jardín, se trataba el tema de los Pórticos, o paseos cubiertos, que se elevaban en plazas y en paseos arbolados. En Madrid carecemos de ejemplos realmente construidos de esta tipología, pero ello no quiera decir que nunca hubiesen intentado edificarse. De hecho se conservan varias iniciativas por parte del Ayuntamiento para realizar este tipo de galerías, que podían ser para el paseo o el comercio. Veremos qué relación guardan con el ejemplo realizado por un alumno de la Academia.

Tenemos un proyecto de 1835, el de José María de Vivar, que desarrolla un Pórtico cubierto para un paseo y que parece conectar dicho paseo, al que vierte la elegante fachada principal, con una zona de jardín tras él. Hubiera sido una bonita forma de poner en relación un parque que se desarrollase perpendicularmente a un paseo; como lo habría hecho, de construirse, la galería, que ya hemos comentado, proyectada por Ventura Rodríguez para el Prado. Este tipo de elementos arquitectónicos tienen una clara dimensión urbana, a parte de estar pensados para el bienestar del público. Son elementos amables que, sin embargo, nunca llegaron a construirse en

\footnotetext{
${ }^{68}$ A.G.P., plano n. ${ }^{\circ} 241 / 3$. Forma parte de las propuestas que realizó Machuca para reformar la antigua Glorieta de entrada al Retiro, que se encontraba en la calle de Alcalá.

${ }^{69}$ Sobre el Casino de la Reina ver: Moreno Villa, J.: «El Casino de la Reina». Arquitectura, XIV, 1932; Corral, J. del: «Cómo Madrid pagó un parque y se quedó sin él. El casino de la Reina», Villa de Madrid, 1972, n. 35-36; Ariza, C.: «El Jardín Botanico, el Casino de la Reina y Vista Alegre, jardines madrileños que fueron del Real Patrimonio». Reales Sitios. 1985, n. ${ }^{\circ} 86$, pp. 37-44. Ariza, C.: Los jardines de Madrid en el siglo XIX, op. cit., 1988, Capítulo «El Casino de la Reina», pp. 86-96; y Rodríguez Romero, E.: «El jardín paisajista y la mujer en España: la Alameda de Osuna, el Casino de la Reina y Vista Alegre», op. cit., pp. 357-359.
} 

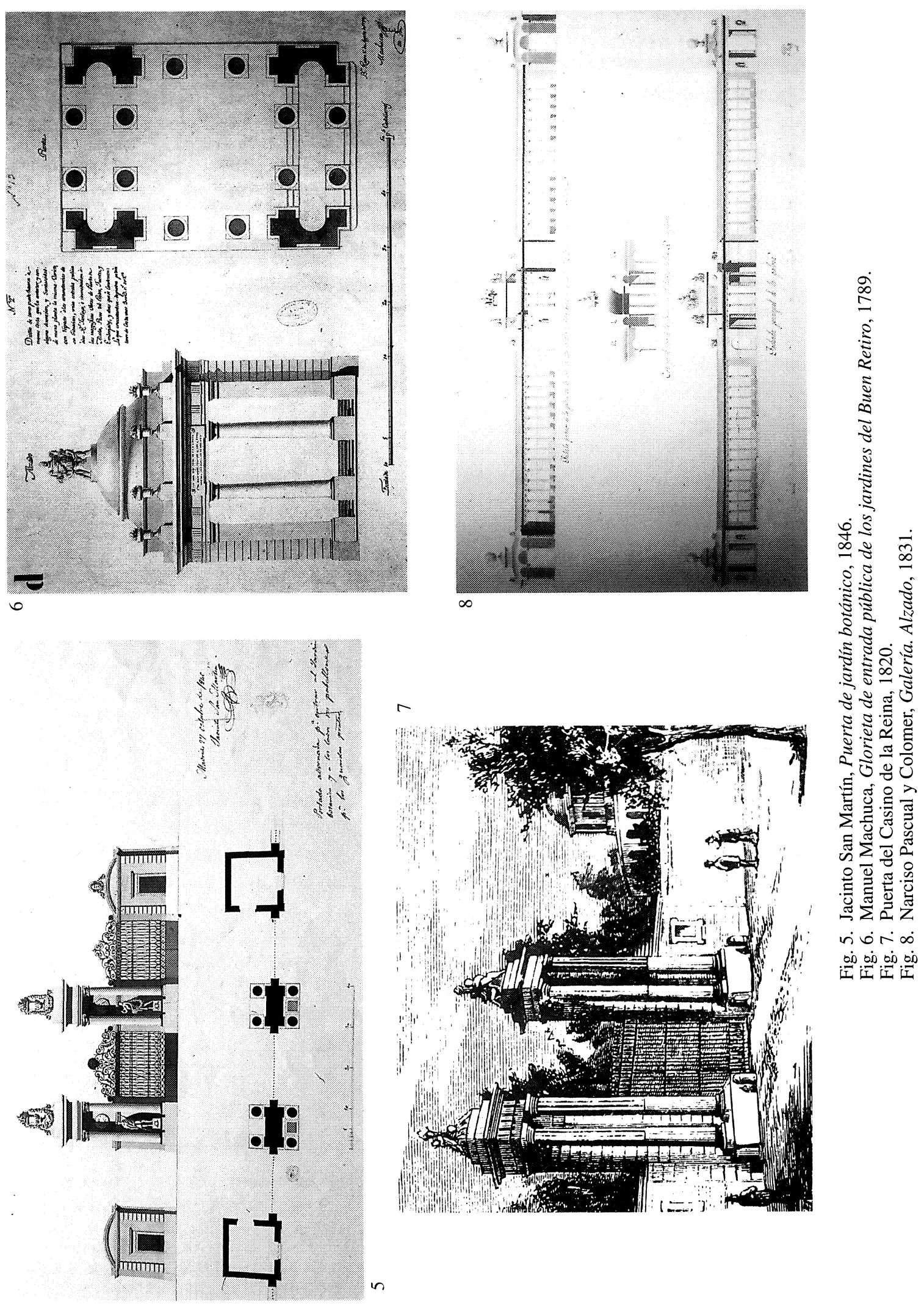
nuestro país, aunque abunden los diseños de este tema, tanto en proyectos fallidos como en dibujos de estudiantes. La función de estas galerías sería la misma que las del Palais Royal de París, tan de moda en aquella época, pero creadas bastante antes. Es destacable el Proyecto de Galería que realizó Narciso Pascual y Colomer ${ }^{70}$ (Fig. 8), en 1831 siendo aún alumno, pensada como entrada principal al palacio de Buenavista. Delimitaba toda una plaza de planta rectangular ajardinada frente al palacio, que hubiera sido un curioso espacio semipúblico entre la calle de Atocha y la Inspección general de Milicias, justo en el cruce con el paseo del Prado y el de Recoletos. Se trataba de un espacio homogéneo de tres crujías adinteladas y totalmente permeables de columnas dóricas. Se singularizaba en su centro con un pórtico que avanza, un friso tallado y una cuádriga como remate, formando casi un arco de triunfo, y se señalaban las esquinas con pabelloncitos que una vez más nos recuerdan a la Puerta Clásica diseñada por Machuca. Bastante posterior a éstas, de 1856, será la Galería del Príncipe de Asturias D. Alfonso, proyecto presentado al concurso para embellecer la Puerta del Sol ${ }^{71}$ y que, construida en hierro y cristal, pretendía proteger del rigor del clima al transeunte que visita el comercio, suponiendo así un beneficio para ambos.

Hasta aquí hemos desarrollado un recorrido a través de las puertas y galerías, elementos ornamentales característicos tanto en jardines y parques como en paseos y plazas, ámbitos destinados al desahogo y paseo públicos en la ciudad decimonónica. Como hemos podido comprobar, estos elementos abundan en los ejecicios propuestos como tema de examen por la Academia de Bellas Artes, así como en la realidad urbana coetánea. Es significativo el hecho de que los proyectos de los aspirantes al título de arquitecto se fundamenten, a veces tan claramente, en ejemplos reales de claro corte clasicista. Es de esperar que, por el contrario, los ejercicios realizados por los alumnos de la recién creada Escuela de Arquitectura, tuviesen un carácter más novedoso e innovador, en la línea historicista de la arquitectura que los profesionales están construyendo por esas fechas.

${ }^{70}$ Gabinete de dibujo. R.A.B.A.S.F., sig. A-3551 y A-3552. Recibió el primer premio de segunda clase de los Premios de la Academia con este proyecto.

71 Proyecto de M. de M. y C., 4 de febrero de 1858, A.S.A., sig. 0'59-8-4. Cfr. Navascués, Pedro: Arquitectura y arquitectos madrileños del siglo XIX, op. cit., p. 157. 